\title{
Discussion on Library Subject Service Capabilities Based on Title Evaluation Mechanisms
}

\author{
Lei Wang ${ }^{1, a}$ and Yue Dong ${ }^{2, b^{*}}$ \\ ${ }^{1}$ Personnel office, Beihua University, 3999 East Binjiang Road, Fengman District, Jilin, Jilin, China \\ ${ }^{2}$ Beihua University library, 3999 East Binjiang Road, Fengman District, Jilin, Jilin, China \\ a513636202@qq.com,b346034656@qq.com \\ * Corresponding author
}

Keyword: Library; Title; Evaluation mechanism; Subject service.

\begin{abstract}
This paper analyzes the main problems existing in library titles evaluation mechanisms, points out the anomaly, impact on work and the level of scientific research; proposes that increasing the library service capacity is development needs; discusses how to improve the subject librarian service capabilities, and points out problems existing in raising subject service ability which should be paid attention to.
\end{abstract}

\section{Problems on the Titles Evaluation in China}

The Status of the Assessment of the Unfair Conditions. The particularity of the work determines the difference inthe division of labor. Therefore, the difference between the workload and the nature of the work leads to the difference between the time and the energy, the communication opportunities of the colleagues, the opportunities for the leaders to understand, and other difference. Which led to the difference in the number of articles, the results of different votes. And the conditions of the review must be the same, so the results are unfair

The Impact of Job Title Assessment on Work. Title promotion will make fame and fortune, will be your ability to work strong proof. The majority of librarians on the degree of attention to the title can be imagined (1) some people in order to assess the title ignored their work, exaggerated boast results. They are busy on writing articles, applying for a project, writing books. Service awareness is weak, although the theoretical level up, but did not bear much work, there is no outstanding work performance, job sense of responsibility is not strong, and even seriously affected the work of other librarians did not play High title librarian role model. But because of the high title, the unit is very important; this is a common phenomenon in today's society (2) heavy conditions of light ability to strong ability, working staff will have a great contusion, is bound to affect the work and affect the development of the library, This is also a common problem.

Interpersonal Relationship in the Title Assessment Has a Greater Impact. Sometimes the results of the assessment surprisingly, this is mostly the result of interpersonal relationships. The work of the library doing well or not, the evaluation of the key is interpersonal relationships, interpersonal relationship is more important than the work itself; colleagues for their own interests in the friction and mutual jealousy, if the usual relationship in general, narrow-minded side will pull in the back of the relationship, In the front of the leadership that the other side of the non-or in the project declaration to play the wrist to the other party to declare the failure; the applicant is not good at the museum leadership, the judges will directly affect the evaluation of the results of the review; some units to assess the annual assessment as one of the conditions, Which is more deep title of the unreasonable assessment of the degree. As we all know, the annual assessment of a large human factors, flow in the form, rarely consider the work attitude, work intensity and academic level, it is difficult to be realistic, fair and just

The Level of Scientific Research in Libraries is Difficult to Improve. Recent years many colleges will arrange exceeding standard personnel of other units or relatives of the introduction members to libraries. They are mainly not professional talented person but they also need to evaluate their titles. So many people only to research data online, collect articles and publish thesis 
on relationships. Another condition is that the subject librarian, their educational background is basically higher, they would like to have an advanced title at an early date. They are also trying to send articles by different methods. Conducting research or writing books. Suppose that who will work hard in such condition, if you don't know job and combine theory with practice, most of the articles and books also piece together. They are out of reality. Even if you publish thesis, is the scientific research level really improved? This is a question for our librarians to think about. Writing articles for evaluating titles is not what we need. Some librarians ask for long leave from work for their titles or go out for a walk in class. They have no sense of responsibility. Librarians are full of utilitarian mind, It seems that we have nothing to do with the issue. It does not matter with our service ability and our scientific research level. 《Xinhua Digest 》 as the authoritative academic information publication throughout the countries. Important achievements in various social sciences are reprinted. But it seldom reprints professional articles in libraries. It shows that our level of research is not high. It doesn't produce extensive social influence. Writing articles for evaluating articles, the level of scientific research is hard to improve.

\section{Improve the Ability of Subject Service}

The subject service of college library has already become improved the service level of the library, main means of improving service effects. Only by continuously improving the service ability of subject librarians can they adapt to the development of new libraries. The service ability of subject mainly include : subject information ability, information literacy educational ability. information technology application ability, teaching scientific research ability and professional ability.

Not only to Enhance Our Professional Knowledge and Professional Ability, but also to Carry Out Digital Source Navigation Service. Digital resources are increasing year by year, which is a great challenge for librarians. Not only have the ability to obtain information and analysis information and the ability to provide targeted information services. So the librarians construct internet resource navigation system according to the personal demand of targeted service. Solve the contradiction between limited energy of service objects and massive information of network.

Develop Embedded Discipline Services. The embedded discipline services is a new service means which organically integrates into the user's physical or virtual space. Most accurately reflects the service concept centered on user. Physical space refers to the adjustment and expansion of the internal and external space of the library. Virtual space mainly refers to the network teaching platform, browser, blogand common websites. The main content of subject service covers six aspects: faculty relation, knowledge information service, literature resources guarantee, information literacy education, full aspects of subject consultation. Space of study and mutual communication.

Construct Subject Service Team. Subject service include two aspects: one is thepersonal service according to the subject divided. Another is the subject contact and to provide professional service. Not only the librarians have solid professional theory language but also the strong scientific research ability. They should have selfless dedication and strong communication ability and team cooperation ability. Because the subject services involve a wide range of content and depth and it requires a team with a clear division of work to complete it. No excellent service ability is hard to competent. Or the subject service only remain traditional low level. The library should construct subject service team to improve service ability.

Define the Responsibilities of a Service Team. In any job, be sure to define your responsibilities and avoid mutual prevarication. The responsibilities of subject librarian is changing with the needs of users, service means, technical means, the allocation of resources, in addition to some traditional service should add the following two functions, one is to strengthen the construction of resources, the two is to strengthen the cyber source navigation

Job Evaluation Should Increase the Amount of Work Performance. The job performance and ability of subject librarians are often considered in job evaluation. Because, whether it is to provide discipline service librarians, or every day adhere to the front-line to provide daily service teachers, 
there are not enough time for research and energy. If we only value scientific research, it is unfair to them. In the United States, the title is only a reference condition, in the process of engagement, the ability to work is the primary consideration, so that subject librarians or librarians have more time and energy to improve their ability to discipline services

The Title Evaluation and Separation. "Evaluation" is just the academic level of certification, "employment" is the embodiment of the actual ability. Strengthening work, played down the title, good is more important than the title; Widely implemented post appointment system in university library, but basically is going through the motions, and didn't have proper incentive effect. The worker is promoted in the title, get all sorts of interests at the same time, should also pay the corresponding, complete the corresponding work hard, but in fact, some people do not bear the corresponding responsibilities, after promotion work more relaxed, service consciousness weak, majority is holding the title mix it then does not have trouble back at home, more have no sense of crisis, title for life did not have the corresponding incentive effect, must be carried out on evaluation and employment separation, and strengthen the management to change; In personal ability. Work performance as an important standard of post appointment, open class, which can motivate librarians to complete their work, but also to arouse the enthusiasm of the service of subject librarian in China.

Establish Performance Appraisal System and Perfect the Mechanism of Professional Titles Evaluation. The performance evaluation standards shall be determined according to the nature of the Department and the responsibilities of the individual. On line service window of the librarian, subject librarian service, should be appropriate to consider the policy tilt, their performance and the operational capacity of title assessment, incentive subject librarians to complete their work, not only academic level up(the theory),the actual work ability of business service capacity, have to keep up with. performance appraisal should be carried out in terms of working ability, scientific research achievements and social benefits. As shown in Fig. 1.

The social benefits are not good evaluation considering its application prospect and the oretical significance, and consider the work performance and content, only for scientific achievements without much work performance, workload lack of librarians, employed the title should be downgraded, at least than the evaluation Title Low Level 1;for the performance, level of progress the librarian award.

\begin{tabular}{|c|c|c|c|c|c|c|}
\hline Assessment index & concrete content & \multicolumn{5}{|l|}{ Score } \\
\hline \multirow{5}{*}{ Job performance } & A、 Target implementation program & 10 & 8 & 6 & 4 & 2 \\
\hline & B、Work quantity & 5 & 4 & 3 & 2 & 1 \\
\hline & C、Work quality & 5 & 4 & 3 & 2 & 1 \\
\hline & D、Work efficiency & 5 & 4 & 3 & 2 & 1 \\
\hline & E、Work method & 5 & 4 & 3 & 2 & 1 \\
\hline \multirow[t]{6}{*}{ Management ability } & A、Decision-making ability & 5 & 4 & 3 & 2 & 1 \\
\hline & B、 Planning ability & 5 & 4 & 3 & 2 & 1 \\
\hline & C、 Organization skills & 5 & 4 & 3 & 2 & 1 \\
\hline & D、Innovation ability & 5 & 4 & 3 & 2 & 1 \\
\hline & E、 communication skills & 5 & 4 & 3 & 2 & 1 \\
\hline & F、 Coordination ability & 5 & 4 & 3 & 2 & 1 \\
\hline \multirow[t]{4}{*}{ working attitude } & A、Obey the spirit & 5 & 4 & 3 & 2 & 1 \\
\hline & B、 Coordination spirit & 5 & 4 & 3 & 2 & 1 \\
\hline & C、Responsibility & 5 & 4 & 3 & 2 & 1 \\
\hline & D、 loyalty & 5 & 4 & 3 & 2 & 1 \\
\hline \multirow[t]{3}{*}{ Professional ability } & A、 Professional level & 108 & 8 & 6 & 4 & 2 \\
\hline & $\begin{array}{l}\text { B 、 The ability to make use of } \\
\text { professional knowledge }\end{array}$ & 10 & 8 & 6 & 4 & 2 \\
\hline & C、Scientific research ability & $10 \varepsilon+r-r-v+2$ & 8 & 6 & 4 & 2 \\
\hline
\end{tabular}

Figure 1. 


\section{We Should Pay Attention to the Problems of Improving the Ability of Subject Service}

To Carry Out a Variety Multi Channel Training. The titles to research articles, although no ground for blame, but not all librarians can write articles written \# professional library, the librarians library is asked to keep on learning, for all librarians to carry out a variety of business training and continuing education, especially the subject librarian; to replenish the outside of the professional the knowledge of the development potential of library should give full play to the subject librarian; improve the professional ability of the subject librarian, can improve the pertinence and effectiveness of subject librarian service, users more quickly obtain knowledge

The Service Ability of Introducing High-level Talents and Cultivating High-level Talents in Libraries. Library lacks high-level talents. To improve the library's academic service capabilities, the most direct way is the introduction of high-level talents, but for the ordinary university libraries it is of great difficulty. Another way is to cultivate the museum Senior titles to improve their academic service capabilities.

The title assessment of the library staff to enhance the quality is of a certain positive significance, at the same time it's of many benefits, but what does it lead to? No attainments; we get a lot, but whether what we do equals what do we have to do with us? Are we worthy of our conscience? Some people think that it is easy to wait for retirement, which is caused by the management mechanism of the library, so the library should take measures to let senior staff Play a positive role. In the foreign countries, the senior titles focus on the overall contribution to the library, rather than the completion of daily work; in the application of senior titles one must pass the defense, the main content of the defense includes work performance, service capacity, academic level. Many of the senior titles in our library are thinking about whether they are conducive to the development of the individual in terms of their work and research. They rarely consider how to improve the service ability and service level, and lack the overall concept. The judges do not need a defense.

\section{Summary}

Title evaluation not only involves people's vital interests and social academic research atmosphere, the work of the library also has a great impact, especially for the library's academic services far-reaching, library service grade upgrade mainly rely on excellent library Staff, only their ability to improve their services to meet the user's diverse, personalized information needs, but also to improve the library's core competitiveness. How to do job title assessment work, to create a fair and equitable assessment of the environment, to restore the title of purity, is a worthy subject.

\section{Acknowledgements}

The Department of education of Jilin province "in 13th Five-Year" planning project, "Research on the construction of the University Library and information institution think-tank (No. GH170055) research"

\section{Reference}

[1] Y.U. Li,Y.Zhang:A study on the professional ability and training ways of Subject Librarians[J].presentAgent information,2016(2):137139, One hundred and fifty-one

[2] X.Pan:On the reform of professional titles evaluation system in University Libraries[J].Intelligence informationMaterial work,2016(6):7780.

[3] J.G.Zhang:Wang Mei.Library talent crisis under the evaluation of professional titlesEngine analysis[J].New century library,2015(12):7579.

[4] L.H. Liu:The mechanism of professional titles evaluation of American Librarians to the opening of Chinese LibrariesIn the[J].Library construction,2015(12):7275.

[5] L.X.Hu:New characteristics of subject service and the core competence of Subject 
Librarians"[J].Journal of Yangtze University,2014(4):203204.

[6] Y.Liu:Research on service innovation model of embedded discipline--Based on the theory of EmbeddednessOn thought [theory][J].Library and information work, 2014(1).

[7] Y.L.Wu:Prospects of academic library service ability[J].Henan booksMuseum journal,2015(5):48449,Fifty-four

[8] Y. Li, Y. Zhang:Research on the professional competence and cultivation of subject librarians [J]. Modern information, 2013 (2) : 137-139,151.

[9] J.L,Zhang, M.Wang:The analysis of talent crisis in libraries under the evaluation of professional titles [J]. New century library, 2015 (12) : 75-79.

[10]X.M:Literature measurement of reading promotion in China [J]. Library community, 2013 (4), $48 \sim 61$.

[11]S.X, Zheng:Study on reading promotion of library reading in vocational colleges [J]. Technical information, 2016, (36) : $231 \sim 232$ 